\title{
Letters from Corona Ground Zero to Helsinki: Notes on the pandemic and the environmental crisis
}

Cartas desde la zona cero del coronavirus a Helsinki: Notas sobre la pandemia y la crisis ambiental:

Toni Lahtinen

University of Helsinki - Finland

Helsinki, Finland

toni.j.lahtinen@helsinki.fi

\section{Panu Pihkala}

University of Helsinki - Finland

Helsinki, Finland

panu.pihkala@helsinki.fi

\begin{abstract}
This is a special kind of article, based on a combination of essay-style writing and references to both academic studies and public discussion. Toni Lahtinen, a Finnish ecocritic, arrived in Seattle just before the outbreak of the COVID-19 pandemic. He sent electronic postcards to Helsinki to Panu Pihkala, a Finnish researcher on eco-anxiety. The correspondence between the two internationally recognized scholars contains first-hand observations and wideranging meditations on global anxieties. One important theme is how the dynamics of othering and privilege are evoked instinctively in threatening circumstances. The first COVID-19 infections in the USA were confirmed in Seattle on January 21, 2020, and until mid-March, the state of Washington had more infections per capita than any other state. Before Lahtinen returned to Finland, 75000 Americans had lost their lives due to the pandemic and the number of unemployed had increased with 20000000 people. The fourteen letters between Lahtinen and Pihkala provoke the reader to think about coronavirus anxiety, eco-anxiety, and methods of coping.
\end{abstract}

Keywords: COVID-19; eco-anxiety; ecocriticism; art; imagination

\section{RESUMEN}

Este es un artículo especial, basado en una combinación de escritura de estilo ensayístico y referencias tanto a estudios académicos como a debates públicos. Toni Lahtinen, un ecocrítico finlandés, llegó a Seattle justo antes del estallido de la pandemia de COVID-19. Envió postales electrónicas a Helsinki a Panu Pihkala, un investigador finlandés sobre la ecocrítica. La correspondencia entre los dos eruditos reconocidos internacionalmente contiene observaciones de primera mano y amplias meditaciones sobre las ansiedades globales. Un tema importante es cómo la dinámica de la alteridad y el privilegio se evoca instintivamente en circunstancias amenazantes. Los primeros contagios de COVID-19 en EE.UU. se confirmaron en Seattle el 21 de enero de 2020, y hasta mediados de marzo el estado de Washington tenía más contagios per cápita que cualquier otro estado. Antes de que Lahtinen regresara a Finlandia, 75000 estadounidenses habían perdido la vida a causa de la pandemia y el número de desempleados había aumentado en 20000000 de personas. Las catorce cartas entre Lahtinen y Pihkala provocan en el lector una reflexión sobre la ansiedad por el coronavirus, la eco-ansiedad y los métodos de afrontamiento.

Palabras clave: COVID-19; eco-ansiedad; ecocrítica; arte; imaginación 


\section{INTRODUCTION}

The objective of this article is to shed light into people's reactions to massive crises. The most evident context is the COVID-19 pandemic, but the letters constantly discuss its relation with other existential crises, especially the global ecological crisis.

The reasons why these crises and people's responses to them are important are almost selfevident: these are major crises of our times, and they threaten not only human well-being and existence but also the flourishing of the planet's ecosystems (e.g. Steffen et al., 2015). If the situation is to be made better, there is a need for more understanding about people's various reactions. In different academic disciplines, the authors of this article have for a long time worked with interdisciplinary research which tries to understand better the major complexities of human behavior in relation to such crises (see Pihkala, 2020a, 2020b; Lahtinen, 2018).

The ecological crisis and the COVID-19 pandemic are fundamentally connected: origins of pandemics such as COVID-19 pandemic are intimately linked with the problems in human relations with the more-than-human world. The ways in which livestock are treated provide opportunities for viruses such as coronaviruses to develop and mutate (Blum \& Neumärker 2021). In addition, in the lived experience of people, various anxieties intermingle. There is much that causes stress and anxiety in the contemporary world: for example, social and economic insecurity, globalization and the many changes that it has brought, and the ecological crisis.

\section{METHODS}

The stress and anxiety caused by the ecological crisis has growingly been called eco-anxiety (Hickman 2020; Pihkala 2020b). One of the authors of these letters, Dr. Panu Pihkala, has specialized in interdisciplinary research about eco-anxiety, and the letters often discuss matters related to it. COVID-19 often causes anxiety and fear on its own (Asmundson \& Taylor 2020), and this coronavirus anxiety resonates in many ways with eco-anxiety, as the authors explore.

The letters are written from two very different cities. Seattle, where ecocritic Toni Lahtinen arrived for a scholarly research period just before the city became USA's Corona Ground Zero, is an international hub, and its metropolitan area has almost four million inhabitants. Helsinki, the capital of Finland, is more isolated in the North part of Europe, even though it is connected with the rest of Europe through the European Union and is a busy flight transfer cite for Asian air travel. As will be seen in the letters, there are some intriguing similarities between the COVID-19 experiences in these cities, but also vast differences. These dynamics provide ground for creative discussion about the role that various cultures, politics and places play for human experience in the 2020 .

The letter format was chosen for many reasons. The lead author, Dr. Toni Lahtinen, is an ecocritic and an artist, and Dr. Pihkala is also a keen amateur in art. The letter format provides explicit possibilities for integration of eco-critical themes into the article. The most fundamental reason for the selection of the format was, however, a desire to explore fresh experiences during the pandemic. Letters written amidst the events make possible another kind of exploration than strictly academic articles which are written afterwards. The letter format reveals emotions and thoughts in the raw, in all their complexity. There may be contradictions, there may arise issues for ethical deliberation afterwards, but in all cases, letters provide information that cannot be captured only by writing retrospectively. Thus, the chosen methodology has some element of autobiography. 
The authors knew each other before starting the reciprocal letter writing process, but not extensively well. As a result, there is an element of getting to know the other better and trusting the other by telling more about one's past. This brings certain intimacy into the letters, even though these are not completely personal letters: the possibility to publish the letters afterwards was recognized from the beginning, which naturally affects the writing process.

Dr. Lahtinen was the first to send letters, and thus the structure of the article reflect this. The letters by Dr. Pihkala often comment on Lahtinen's observations and thoughts about the American COVID-19 situation. After the letters were completed, more references were added, in order to enable readers to find more information about related matters. The titles for the letters were also added afterwards.

\section{Letters between Seattle and Helsinki}

\subsection{Zombie Apocalypse}

Seattle, 16th March, 2020

Toni Lahtinen: Dear Panu, as I arrive in Seattle for my stay as a visiting scholar, it is not the COVID-19 pandemic that first draws my attention but the sight of homeless camps by the highway leading to the city. The cost of living has soared in Seattle with the presence of Amazon and Microsoft headquarters, and the number of unsheltered people has increased dramatically in recent years.

As I make my way past a food bank to the corner store the next day, I am shocked by dire poverty and starkly reminded about my privileged position. After a hearty supper in the evening, I watch Walking Dead on television through a dreamlike haze, and for a passing moment I wonder how much the zombie characters in the series reflect the fears of the American public towards the homeless.

Soon Seattle issues more restrictions, schools having already closed, and flights to Europe are suspended. Only after the quarantine comes into effect, do I think about the series more closely: zombie narratives often depict an outbreak of fatal epidemics or pandemics. Zombies have come far from their Haitian origins and for generations they have become more American. Nowadays they are thought above all to represent American fears towards the unknown, such as ethnic minorities, atomic destruction, communism, globalization, and of course infectious diseases like Ebola, AIDS, or SARS. Zombies are the embodiment of a parasitic virus and revert the threat back to our primitive fear of being eaten. In the TV series Walking Dead, traditional roles are disrupted though. Walls are built to keep the zombies out, but the biggest threat to survival are the people living inside the walls (Crockett \& Zarracina, 2020; also Conrich, 2015; Clasen, 2010).

Only two weeks after my arrival, the USA declares a national emergency and in the media Seattle has become Corona Ground Zero. Articles appear where the spread of the surging pandemic is compared to a zombie invasion (O'Sullivan, 2020). The Californian politician Devin Nunes even describes the situation in his state as a zombie apocalypse referring to its 60 ooo unsheltered people as a special risk group (Mazza, 2020). Psychologist Robert Bartholomew (2020) has already issued a warning in Psychology Today a few weeks earlier stating that the corona crisis is neither a zombie apocalypse nor the end of our civilization, but its dramatic news coverage has the potential to incite panic. Still, the dread of other people's proximity and touch spreads quickly. Even my own compassion towards the unsheltered starts to transform into aversion when a few homeless people approach me on the streets coughing menacingly. 


\subsection{Us and them: a zombie potential in everyone}

Helsinki, 17th March, 2020

Panu Pihkala: Dear Toni, thank you for your postcard. It feels strange reading it here in Helsinki. The university is closed here, too, and I do my research at home. At the same time, the atmosphere conveyed by your postcard takes me overseas. It reminds me of my trips both to the USA and the UK. As I read your text, I remembered my experiences as a teen in London: the bewilderment that unsheltered people sat on the sidewalk. Such things were unknown in the Finnish countryside back then, and even Helsinki did not have these social problems as visibly present as these days.

In January 2011, I arrived in Chicago to do research related to my PhD. The Hyde Park university area was like a fortress in the middle of poor and derelict neighborhoods. I had never encountered such segregation in any European city. Though admittedly, I have not been to the infamous neighborhoods of Paris where inequality runs rampant.

Us and those others. The in-group and the out-group. This is what I contemplated on the most as I read your text. The healthy and the zombies. Those with homes and those without. Good Americans and bad - bad who?

When some are made bad, dirty, or infectious, all manner of angst can be projected onto them. We can try eliminating fears by eliminating those others. In zombie movies this is often done by shooting. During the corona crisis the news have reported that handgun sales have risen dramatically in the USA, even constituting the second highest spike in sales ever recorded (Collins \& Yaffe-Bellany, 2020). Deep anxiety and fear often make people resort to the methods they are accustomed to using as defenses - psychophysically.

This division into us and them also reminds me of a theme that arises from a mutual interest of ours, environmental cultural studies: namely, the different significances of time and place in America and Europe. It has been argued that Americans are accustomed to searching for solutions by moving forward in space, across yet another frontier. European life has been determined more by time since space has already been filled. Europeans have had to learn to live together with different kinds of people within a defined space, or relatively more so than in America (Sittler, 1976). Perhaps this, too, can be seen in the fact that in Europe evil hasn't always been externalized as strongly as in the USA: there are noticeably fewer slums, and zombie fantasies don't intrigue us as much. The differences are of course relative, Europeans have known their fair share of evil, and extreme circumstances especially bring out primitive reactions. And one has to remember that it is the European settlers who ended up practicing the frontier mentality in the US.

It is a tough task: to accept that each of us has "zombie potential," a dark side. But as long as the shadows are externalized, they grow and mutate. It has been proposed in relation to the environmental crisis that the biggest struggle has to be fought in accepting the dark sides of oneself and one's own in-group. The only way to change them is to face them first (Marshall, 2014; Baker, 2017).

\section{Letter 2}

\subsection{Otherworldliness of empty streets}

Seattle, 18th March 2020

Toni Lahtinen: During the first week I have time to stroll around my neighborhood where shops, offices and public spaces are still open, but the streets are already deserted. With a history of several illnesses, a thought has bothered me for years that by some accident or providence I 
have lived past the death I was due. Now, wandering in an empty metropolis evokes such a strong feeling of unreal, of being an outsider, that it approaches the supernatural, almost as if in my earthly travel weariness I was roaming in between life and death.

The chaos caused by the coronavirus leads people around the world to look for supernatural explanations from religious prophecies (Jämsén, 2020). In his classic study The Sense of an Ending (1967) literary critic Frank Kermode has proposed that waiting for the end of the world is actually a way to process the idea of one's own death, a concept difficult to accept. Our sense of time is based on a beginning, a middle, and an end. Therefore, people tend to locate their own life right in the middle of history and to see various changes around them as omens of impending chaos and destruction, and to interpret even real destruction, like wars and disease, as the beginning of the end of the world (Kermode, 1967; also Morton, 2007). Considering that your background is in religious studies, you must have also thought about these questions and these types of explanations.

The sense of otherworldliness grows stronger during the second week when I drift through the ghost town center of a metropolis. As I roam in the valleys and canyons of the mighty skyscrapers, I witness a frightening scenery: the lights of the Space Needle, an icon of Seattle, have been turned off, the headquarters of Amazon are abandoned, the Seattle Great Wheel is standing still by the Pacific Ocean - only the unsheltered keep on lumbering. Disjointed associations keep popping up in my head from the great American classic Moby Dick (1851) where the greatest marvel of the affluent port town of New Bedford is the beggar Lazarus slumped before a rich man's door.

Despite my unique city experience, the sight is already familiar to me from numerous books and films. Personal and shared, lived and imagined intersect in my experience: a major city swept of its residents is a most typical milieu in catastrophe narratives for a world beyond natural disasters, mass destruction and pandemics. Metropolises and their labyrinthine ruins offer a thrilling set for adventure, where collapsed tower blocks, that still reach for the skies, reflect our dreams of grandeur and our fears of death.

In a ghost town the past is still present as ruins and relics but is now unreachable. Therefore, they often trigger in us yearning, regret, nostalgia, or a sublime allure (see Huyssen, 2006). In many novels and films the empty, maze-like cities are also mental landscapes for loneliness, estrangement, and the disintegration of the psyche. This is how metaphors function as strategies of thought that help us try to understand a world where the familiar and the strange are in a constant state of flux (see Larsen, 2004).

\subsection{Liminality, eschatology, and rites of passage}

Helsinki, 21st March, 2020

Panu Pihkala: The beginning of your postcard summons up several images from the hidden corners of my mind: scenes from films, novels and dreams. Such spaces that are both the same as before and yet somehow completely different stir something in us. Precisely because I have long researched the relationship between religion and environmental questions, did your postcard bring up the themes of liminality and eschatology so palpably. Both words naturally require explanation. Anthropologists and religion scholars have noticed how significant transitional periods have thresholds, limes in Latin. When a person has gone over a threshold, the world is simultaneously the same and yet completely different (e.g. Turner, 1969).

Eschatological situation, that is situations where the end of times is present in some potent way, 
are of course powerfully liminal spaces. Religion scholars distinguish between apocalypses, more powerful descriptions of the end of the world, and broader eschatology. When someone preaches that the end of times is near, it is a case of eschatological communication, even if there is no sign of an actual apocalypse (on eschatology and the environmental crises, see e.g. Skrimshire, 2010).

The environmental crisis has been described as an enormous, global rite of passage (e.g. Purdy, 2017). We are on our way; there are many dangers ahead, but at the same time there is great potential for renewal - or, actually, a necessity of transformation. The corona crisis further amplifies the sense of a rite of passage or tribulation (Assadourian, 2020).

The more unusual the imagery, the greater the sense of threat, psychologists remind us. And the corona crisis is full of highly unusual imagery (Leahy, 2020). Apocalyptic fiction comes to mind for many of us, as you mention. Major cities that are in some ways the same and still different. Some comments explicitly state that the start of the pandemic felt like the beginning of the end of the world (e.g. Onali \& Mahlamäki, 2020).

We have already talked about dystopias in Finland before all this. It would be interesting to talk some more about the fascination with abandoned places. Why are ruins and sunken shipwrecks so enchanting? Why are partially abandoned metropolises so intriguing, or ones that have fallen to ruin?

As a researcher of eco-anxiety, it would be tempting to say that we are processing death and ecological change here. But at the same time, there is something fundamentally human about all this. The fascinating and the frightening merge together. Curiosity, and a hope that uncertainty may also hold new possibilities.

The streets of Helsinki are so very empty, and people avoid each other. But the feeling of strangeness is not as strong here as in a metropolis. Here emptiness does not surprise as much when there are fewer people to begin with and people tend to be introverted no matter the situation.

\section{Letter 3}

\subsection{Various reactions to an un-silent spring}

Seattle, 25th March, 2020

Toni Lahtinen: There is a long queue to the corner store and safe distances vary depending on people's thoughtfulness. The peace of the quiet queue is disturbed by an unsheltered man who is searching for something, or perhaps nothing, at people's feet. A bit further away a young woman with her hat pulled down her face is begging for money - she can't have been living on the streets for more than a few weeks. There are posters glued to the lampposts entreating landlords and ladies to forgive arrears due to the corona crisis.

They only let a small number of people into the store at a time. You cannot bring your own bags into the store for hygiene reasons. Most of the customers are wearing masks according to recommendations, bought or DIY. Hands need to be disinfected as you step into the store. People go quietly round the aisles and each other. In three weeks, encountering others during your every day shopping has become a tense event, shadowed by the fear of death even. The fear has grown so rapidly that in the media educational psychologists already advise cultivating children's capacity for empathy towards the disadvantaged and elderly so that we do not distance or isolate ourselves too much (Boudreau, 2020). 
As I leave the store, I buy the newest issue of Real Change from a street vendor - the proceeds of the newspaper go to the underprivileged in the area. The main headline - Silent Spring. The city shuts down - repurposes the famous metaphor of Rachel Carson's Silent Spring (1962). In Carson's book, the chemical industry poisons a rural village, and the arrival of death is signaled by the silence of birds, a metaphor borrowed from the Book of Revelations. The cover illustration features the familiar Space Needle and local magnolia trees in bloom, but pink and crimson viruses grow on the branches instead of leaves. The media illustrations of the virus often use hues of red because in nature the color functions as a warning and is thus also a signal for the human brain (Weaving, 2020). Perhaps the editors of the newspaper are also aware that the word virus is derived from a Latin word meaning poison.

The dead silence that has fallen over the metropolis challenges one global megatrend urbanization. Originally metropolis meant parent city, but later it has become a more general city model that has been considered to create welfare. The rate of urbanization is already very high in the economically developed countries, and the city itself has almost become an unquestioned solution to ever greater economic growth and efficiency. My thoughts are not unique on this either: soon an article from Aamulehti, the daily newspaper of my hometown, drifts in front of me from the waves and vortexes of social media - it tells that researchers have long warned people against cramming so densely into urban areas where it is impossible to control the spread of dangerous viruses (Wallin \& Peltomaa, 2020). When I read the article, I cannot stop thinking that Näsinneula, the landmark of my rapidly growing hometown, was actually built-in imitation of Seattle's Space Needle.

\subsection{Psychosocial dynamics}

Helsinki, 2nd April, 2020

Panu Pihkala: Finland has not seen an event that impacts people's everyday life like this since World War II. Of course, the situation is far from a war, but the exceptionality is still startling. I have studied these phenomena primarily by comparing eco-anxiety and coronavirus anxiety (Pihkala, 2020a). These issues require psychosocial research which studies both the personal and the social. There's a lot of variation in the phenomena that are described as anxiety.

In the early 2010s, when I had been reading environmental research for a decade, I got interested in psychodynamic environmental studies. The inconsistencies in people's environmental behaviors were - and are - just so enormous that they cannot be explained by simple theories of value differences. Something deeper and quite primitive seems to be going on (Hoggett, 2019).

The corona crisis brings out humanity's fundamental characteristics in great clarity. It reveals both selfishness and compassion. For example, a new kind of neighborly help has genuinely been touching in Finland. At the same time, it is terrifying, but unsurprising, how some people defy common ground-rules. Globally it sickens me how some super-rich fly to their private bunkers (Neate, 2020) and right-wing populists practice opportunism to bolster their power.

This situation has affected environmentally conscious people in a variety of ways. Some are deeply disappointed and anxious because all attention is now on COVID-19 and not on environmental issues. However, many people have also expressed hope. It is now clear that modern societies at their best can also take drastic action. Many yearn that at least something as substantial would be done on environmental issues (e.g., Heglar, 2020; Brooks, 2020). 
Profound thinkers have pointed out that in practice this is all just one corona crisis where both environmental dimensions and COVID-19 are intertwined. The Finnish multidisciplinary research group BIOS published an excellent text on this (BIOS, 2020). The ongoing, multifaceted crisis happens on all levels: ecological, social, and psychological. The most fundamental level has to do with the carrying capacity of ecosystems though, since without it everything falls apart. In the middle of the corona crisis, it is absolutely essential to be able to create such path dependencies that take us towards greater ecological sustainability.

It is interesting that Rachel Carson has been brought up again. I also realized that we haven't really talked about her before even though both of us have studied her thinking and impact. Carson's temperament, reflected in the style of her texts, has moved me deeply. In addition to Silent Spring, her sea trilogy and her essay "Sense of Wonder" have been important to me. The author's style tells us something fundamental about her persona and worldview. Carson's style expresses a view of life where you breathe in deep the wonders of nature but at the same time fight hard for social justice (Stoll, 2009).

Carson is a typical example of the kind of communication psychology that is also related to environmental questions. The same pattern has been seen time and again, but rarely with so much force. A brave messenger manages to uncover an environmental problem. Those with economic or power related interests on the matter attack her viciously. If the justified anger of citizens can merge together and become a mass movement, changes happen (Lockwood, 2012). I wonder where all the corona feelings will eventually be channeled into?

\section{Letter 4}

\subsection{Dreams for recovery of nature}

Seattle, 5 th April, 2020

Toni Lahtinen: Contrary to the headline of Seattle's silent spring, resounding birdsong fills the evenings as car traffic has ceased. Unlike Carson's biblical fable, the disappearance of birds is not the first symptom of a city infected with a virus after all. Instead, news are pouring in from all over the world of the revival of nature: the clear canals of Venice are full of dolphins (Wray, 2020), the peaks of Himalaya are visible for the first time in 30 years (The Weather Channel, 2020), curious coyotes are roaming near the Golden Gate bridge (ABC7 News, 2020). These pastoral images evoke hope that humanity will rise up to make a more rigorous effort to combat climate change. On the other hand, the media also offers counter narratives, like the starving monkeys of Thailand who are attacking each other with unprecedented ferocity as the tourists that feed them have disappeared (Ratcliffe, 2020).

In addition to your postcard and the messages of worried friends and family, sad news reaches me from Finland - Pentti Linkola has died, a lone voice in the wilderness has fallen silent. A feeble prediction that one virus will not change humanity, will remain Linkola's last prophecy (Kiviniemi, 2020). Linkola's writings have in many ways anticipated modern environmental discussions, but still we cannot accept his simple testament in our daily lives: the use of natural resources must be reduced. The coronavirus stopped Asian factories and Western business life and is therefore also considered an economic pandemic, whose cure will probably be based on an intense growth of consumption and competition.

It is precisely the loss of Western welfare that is at the heart of many dystopias of our times, which might imply an answer to a question puzzling so many: why don't we react as boldly to threats more serious than the coronavirus? As journalist and non-fiction writer Charles Eisenstein (2020) points out in his corona essay, about five million children die of hunger worldwide every 
year, but not a single nation has declared a national emergency or regulated its everyday existence to save these lives. Of course, most of the deceased live in the developing countries of Africa and Asia. On the other hand, the pandemic is now transforming into a food crisis in the USA: as millions have become unemployed, the demand in food banks has grown eightfold in some parts of the country (Lakhani, 2020).

In Finland Linkola's death - a man who lambasted the Western lifestyle and chose to live in scarcity - will set in motion genuine grieving for the loss of the literary intellectuals of the postwar generation (Krohn, 2020). Predictably, a bickering that will not spare the batteries of smart phones will also commence on the ecofascist aspects of his philosophy. A rather harsh comment about Linkola's death appears on the Facebook page of a journalist who has researched online hate and no one objects. It declares good riddance to that fucker. This commentator is another journalist and author, who, according to their publisher's website, is a person interested in a comfortable and extravagant life. The short obituary paints a picture of our modern intellectuals who wobble in prosperity: childish taunting in virtual bubbles.

\subsection{Looking for symbolical immortality}

Helsinki, 8th April, 2020

Panu Pihkala: Over the past five years I have tried to discern what kinds of emotions are at play below the surface of the human mind in relation to environmental issues (Pihkala, 2020b). Your postcards and these corona times bring up many of those underlying currents.

I was also thrilled by the news of the dolphins' return. A couple of days later I noticed that it was fake news. A good article on the subject appeared on the website of National Geographic. Psychologists are looking at what kinds of hopes are reflected in the popularity of these nature related fake news. On the one hand, nature and animal pictures simply cheer us up in the midst of oppressive times. On the other, environmental psychologist Susan Clayton brings up a deep psychological theme: people really want to believe in nature's ability to recover (Daly, 2020).

For years I have been deeply impressed by the work of psychologist Robert Jay Lifton. He has studied hard topics, like the survivors of Hiroshima, the psychology of Nazi doctors, and ecoanxiety. Lifton noticed that initially one of the central fears of Hiroshima survivors was that nature itself would be destroyed. From this observation he later derived one form of so-called symbolic immortality or ways in which people search for meaning that transcends mortality (Lifton, 2019).

People often experience a deep, often unconscious need to know that the world of nature will continue its cycle even after their own lives have ended. Various manifestations of this need are often there deep within even today's urbanized and technologized people. They intertwine with subconscious eco-guilt and at worst paralyze us in shame: What on earth have we done to the world of nature? (Jensen, 2019.)

I see inverse reflections of these deep emotions in the memes and fake news of the sudden recovery of nature during the corona crisis. Our guilt is redeemable after all. Birdsong returns.

Non-Finns will probably find it hard to understand the status that environmental philosopher and fisher Pentti Linkola has held here for decades. His status is strongly connected to eco-guilt and a complex longing for a connection with nature. Linkola has been a kind of ecological superego, a severe reminder of guilt and shame. At the same time, his close-to-earth lifestyle has been the object of secret dreams although something that we are not ready for in real life. This kind of ambivalence might well explain the violent reactions that the advocates of self-sufficiency have to face. Of course, Linkola himself also incited these reactions by his own comments related to 
violence. The sensitive lover of nature might well blurt out that he wished the human population would dramatically decrease.

\section{Letter 5}

\subsection{War, enemies and existential crises}

Seattle, 11th April, 2020

Toni Lahtinen: I am surprised that there are so many fake news about the recovery of nature even though I notice that here especially I am suspicious of the trustworthiness of every single news channel. Just the other night the president of the USA, Donald Trump, declares in a press briefing that the country is at war against the coronavirus and promotes himself to a wartime president. The metaphor of war spreads in the media as fast as the virus, although I am not entirely sure that Trump is its patient zero. Even one of Trump's most prominent critics, New York governor Andrew Cuomo refers to healthcare workers as the country's soldiers. Despite political affiliations, the country is finding a common enemy, the coronavirus.

These days the significance of every phenomenon is analyzed immediately online. CNN quickly outlines the similarities of the states of emergency caused by war and the virus: during a pandemic decisions are a matter of life and death similarly to war, in both cases the enemy can attack at any time, and battles are fought both on the frontlines and at home. War is a metaphor, that mobilizes people to act in a situation that can claim lives and require different kinds of sacrifices: citizens must follow guidelines on social distancing and companies must direct resources toward stopping the pandemic. On the other hand, metaphors of the virus's sudden attacks on nations feed nationalism and create potential for the consolidation of power, as is now happening in Hungary and the Philippines (Levenson, 2020). For Trump, the virus from Wuhan offers aggressive war rhetoric with which he enters into the election battle challenging not only his opponent but also China's strengthening role in the world market.

Even before Trump's speech, I had already thought about how people must have felt at home during the World Wars, anticipated or sensed the death raging elsewhere in the world. I am haunted by thoughts as I lie awake in bed at night due to my chronic insomnia, but also as I strive to understand the real scale of the pandemic and the human suffering it causes. My second reaction to a national emergency is unconscious at first. Without understanding why, I am preoccupied with my own childlessness. This reaction, too, seems species-specific, since a rise in birth rates has often followed large-scale shocks, like war, that have faced humanity (Lepistö, 2020).

By contrast, I think very little about my near and dear back on the home front, if at all. However, this is a trick my mind plays on me, since at night my loved ones appear to me in restless sleep. As I close my eyes I see, for example, nightmarish images of my mother who suffers from dementia: she cries out in panic, like a small child, locked in a dark room she can't get out of without my help.

\subsection{Apocalyptic dreams}

Helsinki, 14th April, 2020

Panu Pihkala: War, battle, struggle - fundamental frames of the modern system of thought. They have indeed been used to combat all kinds of problems. Many environmental philosophers point out that attacking environmental problems does not solve the underlying problems because the enemy is in the attack culture itself (e.g. Foster 2019). 
The more anxious the times are, the greater the psychological need to blame someone, to attack someone, and preferably to externalize guilt altogether. This has also been seen with environmental questions, the social issues related to unsheltered people, and now with COVID-19. It is terrifying how easily toxicity merges with other prejudices, like skin color or nationality. Trump's speech about a "Chinese virus" is extremely damaging.

An existential crisis reveals fundamental characteristics underneath masks. Amazing goodness emerges from some people, evil from others, both from most. For me, one of the most arresting, although unsurprising, reactions during the corona crisis was the Brazilian president Jair Bolsonaro's comment that the coronavirus is his opponents' plot to weaken his position. A thirst for power rarely comes out with quite so much brutal bluntness. It makes me think of Shakespeare who exposed the dark hearts of the power hungry in many of his plays.

I well recognize the phenomenon you write about: how the individual can sense societal anxiety. This is a familiar phenomenon within eco-anxiety research. Your dream is also very moving. It seems to illustrate fundamental psychic images.

Years ago (1994) Michael Ortiz Hill wrote a book about apocalyptic dreams. It revealed how themes of nuclear and environmental destruction reside in people's unconscious. It seems that people share a kind of apocalyptic landscape and process it in their dreams. The world being poisoned is one of the central themes. According to many other psychologists as well, apocalyptic dreams are a sign that transitional stages are at hand both in the individual psyche and in the world (Gillespie, 2020). The book was thought-provoking but very heavy to read. Dreams take us so deep.

I wonder what kinds of dreams people on the whole see these days? How do environmental threats and the climate crisis merge with pandemic fears? I noticed that researchers have already started to study this, and ask people to send in information about their experiences (Niinistö, 2020; Lang, 2020).

I think about your dream, the one you mentioned, and about your thoughts on childlessness. In my previous postcard I wrote about the theories of Robert Jay Lifton. One of the central forms of symbolic immortality is biological, and it has to do with offspring or children. This might be one reason why thoughts of childlessness emerge during the corona crisis. People consider what kind of a mark they leave on the world if they should die. On the other hand, for those with children, crises can mean an increase in worry: what will happen to the children? Many people have said that this is their central anxiety in relation to the environmental crisis.

The theme of symbolic immortality brings my thoughts back to the first theme of this postcard, war. A nation at war is persuaded to believe that the sacrificed lives gain lasting meaning: they have died for others, so that others may continue to live. What about those who died because generals made such bad decisions? Will there be something akin to military cemeteries for those who have fallen in the COVID-19 battles?

\section{Letter 6}

\subsection{Chris Cuomo and a television that becomes turned off}

Seattle, 15th April, 2020

Toni Lahtinen: One commonality between wartime and the corona pandemic is the growing significance of news coverage and the spread of disinformation, propaganda, and rumors. At first, I approach the political rants and pathos of American news broadcasts with European arrogance 
and amusement. In the beginning of my trip, I amuse myself with a news program called Chris Cuomo Prime Time, whose white-teethed and strong-jawed host Chris Cuomo is Governor Andrew Cuomo's little brother. Sometimes Chris interviews Andrew about the deteriorating situation in New York, and their squabble over who is their mother's favorite son is a running gag of the show, even if there seems to be something sore beneath the laughter.

As the number of infections grows exponentially, the news starts to become oppressing. The USA surges into the lead of nations in crisis, and the swelling numbers of tens of thousands of infections and thousands of deceased run tirelessly on the screen from morning till night, nonstop. These are followed by emotional features of the victims of the virus and their inconsolable families. Until a tragicomic twist occurs: Chris Cuomo has been infected! Now this hypermasculine anchor of steel cries on live television, pale and weak: he broadcasts from home during his usual slot and describes his horrible, feverish corona pains.

Cuomo's illness triggers in me an unbearable anxiety, and I begin to plan an immediate return to home. Risk psychologists have noticed that both real and imaginary stories about individuals produce stronger empathy than numbers, and thus they are an effective way to influence large audiences (Slovic \& Västfjällen, 2015). For me the decisive psychological trigger is the theatrical pain of a plastic television personality who loves his mother. During my social distancing, I have bonded with him in much the same way as with protagonists of literature and films. The compound effect of great numbers, individual fates and loneliness is panic. This, too, communication researchers could have predicted: it has been noted that the repetition of shocking images produces paralysis, hopelessness, and anxiety in audiences (Lowe et al., 2006).

The television remains off for days and suddenly my strength come back, I decide to stay in the country, as if awakening from a dream or pulling myself away from a bad movie. I feel so childish now after momentarily surrendering to the surging panic and overindulgence in which a hunger for news is boosted by many irrational personal fears that are perhaps not even connected to the virus. I also give up my compulsive need to understand the situation fully: even expert opinions vary from the greatest pandemic of the century to the greatest fiasco of the century in which the countermeasures that so severely try Western prosperity and welfare are feared to be excessive (Barrett, 2020).

Instead, with the help of the omniscient Google, I quickly discover that according to preliminary research, the American media has played a significant role in inciting national panic - search spikes are closely linked to the most dramatic news coverage (Leetaru, 2020). To my surprise, the search words 'coronavirus,' 'panic', and 'media' also lead to Google results about the growing panic withing the media industry. As morgues fill up and refrigerated containers arrive in front of hospitals, advertisers are preparing for an economic recession and have started pulling their adds, and journalists are being laid off across the world. In the USA alone, the projections predict a similar recession for the industry as after the 2008 financial crisis when just the newspaper revenues dropped by nearly 20 percent (Johnson, 2020).

\subsection{Self-care: Limiting media exposure}

Helsinki, 18th April, 2020

Panu Pihkala: Your example of Chris Cuomo is interesting. I recognize the media's influence well. I was also surprised by the very physical stress symptoms I started feeling when I read corona news in March. Even though I have years of practice in tolerating and channeling stress caused by global problems. Perhaps COVID-19 caused an overload, or perhaps the cumulative total impact grew too big, or then death anxiety emerges more strongly during a pandemic. 
Now I understand better those people who suffer from worse climate anxiety symptoms than I have ever suffered. I have listened to their worries in my discussion groups and workshops: they describe how all kinds of things can remind them of the environmental crisis (Pihkala, 2019; cf. Hickman, 2020). By fall 2019, many of those working on environmental issues say that they have nearly stopped following the news live because the psychic stress is too great.

It was difficult to stop checking the COVID-19 news in the mornings. I did it anyway. I reserved half an hour for it in the middle of the day. In the evenings and on the weekends, I don't check my emails, follow news services, or use social media in any case. I'm not exactly an introvert, but at the same time I'm aware of the fact that those who are more social than I am, find it difficult to put similar restrictions in place. Still, we really should reduce our media usage to keep our sanity. Practically every single psychologist, who has commented on living with the corona crisis, has recommended this (e.g. Kecmanovic 2020).

I have thought a lot about exceptionalism, the belief that you are special in some way. Many have exhibited this quality in connection to the coronavirus, starting from news anchors. I follow the news of Sweden's COVID-19 strategy in bafflement. I pause reading an article where the reporter says that Swedish officials don't express condolences to the families of the deceased. Instead, they highlight the fact that mostly the deceased are the most elderly (Pelli, 2020).

The classic and contested book by cultural anthropologist Ernest Becker, Denial of Death (1974), has been on my mind a lot. People run away from death in all kinds of ways. Charles Eisenstein, whom you also mentioned, writes about the war against death. I wonder if this is the core of coronavirus anxiety. Societies like Sweden and the USA - or their more prosperous and privileged citizens - are not used to the presence of death, let alone accepting mortality. A pandemic brings mortality close and intensifies defenses until they break, or the crisis ends. Death is cleared away out of sight, even condolences are instinctively left unsaid, and people desperately hold on to their own invulnerability.

\section{Letter 7}

\subsection{Frames}

Seattle, 22nd April, 2020

Toni Lahtinen: During the pandemic I have focused on my research more rigorously than in months. All the hurry has disappeared from my everyday life, but it is also a question of managing loneliness and worries. On the spur of the moment, I bought a little book called The Short Story of Art (2017), and I look at pictures of masterpieces of painting to calm my mind as it toils away into the small hours of the night. In addition to working, I channel difficult emotions into different pieces of art. Many of the centuries old paintings now speak to me about the state of emergency that has sprung up around me, like Delacroix's arrangement on the massacre of Chios Scène des massacres de Scion (1824) or a Byzantian mosaic (c. 1261) where the holy mother prays for compassion from a gentle-faced Christ Pantocrator who passes judgement on the last days of humanity.

My thoughts rest especially on Claude Monet's calm landscape Impression, soleil levant (1872), although if it were not for the isolation, I probably wouldn't be especially drawn to its hazy paleness. The impressionist piece, quickly painted, portrays the port of Le Havre at dawn, although I stubbornly look at it as a sunset in order to persuade myself to sleep. Monet describes the harmonious landscape as a passing moment, an impression as the impressionists have it, that shies away from allegories and fictionality in all its realism. The sunlight shimmers on the ageless surface of the sea, and the morning mist makes the silhouettes of the ships on the horizon appear 
like trees rising from the opposite shore. As I look at the painting, I imagine the serenely rising and falling breast of the sea, a warm and salty breath, the infinite and endless movement of life.

However, Monet's lyric landscape starts to transform in my mind the deeper into its haze I dive. As I look up more information about the piece, I discover that the mist that has enraptured me is in part industrial smoke from the painter's hometown of Paris. The seemingly pure and harmonious impression starts to change into a narrative after all where the painting, that has been interpreted as a patriotic utopia, celebrates the resurgent industry and commerce of France after the lost war. What is more curious is the fact that the composition of the painting and the beauty of the complementary colors of orange and blue is perplexingly close to Seattle's silent spring in the cover illustration of the newspaper that I bought. On the front page of the local paper, the horizontal line is formed by the treetops of magnolias that merge with the clouds, above them a purple coronavirus rises or sets instead of the sun in a lilac sky. And so, one piece of art frames the window through which I see both what I want to see and what I don't want to see.

\subsection{Meaning-focused coping}

Helsinki, 25th April, 2020

Panu Pihkala: You said you were focusing on research. It sounds familiar. When the restrictions were put into place, I applied a psychological method familiar to me from my eco-anxiety days: looking at the phenomenon from as many angles as possible and writing about it to others. I prepared an hour-long university lecture on the relationship between coronavirus anxiety and eco-anxiety: similarities and differences. Because I remained healthy, I also wrote a shorter English version (Pihkala, 2020a).

I would have been happy to continue the same method of coping. But with the kids at home and working in two-hour shifts with my spouse, everyday life gains a whole new dimension. Projects that have long been in preparation come to a standstill and frustration grows. At the same time, I have a strong feeling, that I shouldn't complain about any of this because at least everyone close to me is well.

With the environmental crisis, too, the knowledge that some suffer more than others creates a lot of psychological pressure. Sometimes even guilt and shame. A kind of survivor guilt torments us. We'll see how it falls into place once the worst phases of the corona crisis are eventually over. Those who survived the disease may experience this, but what will happen with environmental guilt?

I am glad that you stumbled upon an art book. Intuitively I have also been browsing art books more than in a long time. The landscapes of Caspar David Friedrich rejuvenate me. In them, human life becomes just a part of nature's many shades. I also pay close attention to the progress of the physical spring. We had a so-called climate winter in Finland: a completely atypical snowless season. It was difficult to enjoy the flowers that bloomed out of season (Pihkala, 2020c). Now, after all the cold spells, spring is on schedule, and it is easier to take joy in it. At the same time, I notice that the crisis always occupies a part of the mind's territory, almost like a part of the processing power of a computer. The "programs" running in the background make other activities slower and more difficult.

Still, the song of blackbirds is so beautiful and enlivening on the leafless branches of east Helsinki maples. I go hiking a lot with the children when my wife works, and we enjoy the nature nearby. The spring is not silent, thanks to Rachel Carson and all the other champions. Argh, a war metaphor again; it is difficult to avoid influences. In any case, you get used to a crisis. The times of interweaving crises continues, full of uncertainty and the anxieties that come with it, 
and at the same time full of potential for meaningful action. The simultaneous knowing and notknowing continues: balancing between strategic ignorance, the urge of denial, and good living in the moment.

\section{CONCLUSION}

The objective of this article was to shed light into people's reactions to massive crises. As was presumed, the letter format helped to observe and record fast-moving social phenomena. The discussion moved to places and themes that the authors could not have foreseen before. The result is both a creative process and a testimony to the complexities of lived experience during strange times.

The authors observe several themes that could be discussed much further in future studies and writings. A major example is the theme of social prejudices and xenophobia. In the research published since the writing of these letters, it has been noticed that there is much prejudice related to COVID-19 stress. For example, one of the scales that were developed to measure COVID-19 fear and anxiety, the COVID Stress Scales and the related proposal for COVID Stress Syndrome (Taylor et al. 2020), integrates xenophobia in it, because it was noticed to be so widespread during the pandemic.

Ways of coping with COVID-19 anxiety have also received more attention since the writing of the letters (e.g. Coelho et al., 2020). Closely related to the topics of this article, there has appeared research on the role of the arts in coping with pandemics (Potash et al., 2020; Lakh, Shamri-Zeevi \& Kalmanowitz, 2021). Since the arts have been recognized also as highly important means in coping with eco-anxiety (e.g. Bentz, 2020), this topic of the arts and coping with global anxieties clearly merits further research. This collection of letters is itself an instance of related dynamics, hopefully also for readers.

\section{REFERENCES}

ABC7 News (2020, April 18). Coronavirus: Coyote explores Kirby Cove beach near Golden Gate Bridge as COVID-19 keeps people indoors. $A B C$ https://cutt.ly/qmnwVmh

Asmundson, G. J. G., \& Taylor, S. (2020). Coronaphobia revisted: A state-of-the-art on pandemic-related fear, anxiety, and stress. Journal of Anxiety Disorders, 76, 102326. https://doi.org/10.1016/j.janxdis.2020.102326

Assadourian, E. (2020, April 7). Is COVID-19 a Collective Rite of Passage? Resilience. https://cutt.ly/omnw8EC

Baker, C. (2017). Dark gold: The human shadow and the global crisis. iUniverse.

Barros-Grela, E. (2018). Past Future Cityscapes: Narratives of the Post-Human in Post-Urban Environments. In, M. Koren-Kuik and \& Y. Maurer (editors). Cityscapes of the Future. Urban Spaces in Science Fiction (pp. 28-48). Brill / Rodopi.

Bartholomew, R. (2020, January 27). The Chinese Coronavirus Is Not the Zombie Apocalypse. Psychology Today. https://cutt.ly/Smnw7qA

Barret, J. (2020, March 18). Stanford Professor: Data Indicates We're Severely Overreacting to Coronavirus. Daily Wire. https://cutt.ly/Nmnw7HQ

Bentz, J. (2020). Learning about climate change in, with and through art. Climatic Change. http://doi. org/10.1007/s10584-020-02804-4

BIOS (2020, April 7). Quick, slow and intertwined crises - ecological reconstruction in an uncertain world. https://cutt.ly/mmnewOS [Finnish original version published 25th March 2020]

Blum, B. \& Neumärker, B.K.J. (2021). Lessons from Globalization and the COVID-19 Pandemic for Economic, Environmental and Social Policy. World, 2, 308-333. https://doi.org/10.3390/world2020020

Boudreau, E. (2020, March 18). Cultivating Empathy in the Coronavirus Crisis. Usable Knowledge, Harvard 
Graduate School of Education. https://cutt.ly/3mnetEY

Brooks, R. P. (2020, May 1). Will Civilization's Response to COVID-19 Lead to a More Sustainable, Equitable World? Resilience https://cutt.ly/5mneyBV

Clasen, M. (2010). The Horror! Evolutionary Review, 1(1), 112-119.

Coelho, C.M., Suttiwan, P., Arato, N., \& Zsido, A.N. (2020). On the Nature of Fear and Anxiety Triggered by COVID-19. Frontiers in Psychology, 11, 581314. https://doi.org/10.3389/fpsyg.2020.581314

Collins, K. \& Yaffe-Bellany, D. (2020, April 1). About 2 million Guns Were Sold in the U.S. as Virus Fears Spread. New York Times. https://cutt.ly/vmnenPq

Conrich, I. (2015). An Infected Population: Zombie Culture and the Modern Monstrous. In, L. Hubner, M. Leaning, \& P. Manning (editors). The Zombie Renaissance in Popular Culture (pp. 15-25). Palgrave McMillian.

Crockett, Z. \& Zarracina, J. (2020, October 31). How the zombie represents America's deepest fears. Vox. https://cutt.ly/xmneQ9y

Daly, N. (2020, March 20). Fake animal news abounds on social media as coronavirus upends life. National Geographic. https://cutt.ly/DmneECy

Dodds, J. (2011). Psychoanalysis and Ecology at the Edge of Chaos: Complexity Theory, Deleuze/Guattari and Psychoanalysis for a Climate in Crisis. Routledge.

Eisenstein, C. (2020, March). The Coronation. Charles Eisenstein's website. https://charleseisenstein.org/ essays/the-coronation/

Foster, J. (Ed.) (2019). Facing Up to Climate Reality: Honesty, Disaster and Hope. Green House Think Tank \& London Publishing Partnership.

Heglar, M. A. (2020, March 25). What Climate Grief Taught Me about the Coronavirus. The New Republic. https://newrepublic.com/article/157059/climate-grief-taught-coronavirus

Hickman, C. (2020). We need to (find a way to) talk about ... eco-anxiety. Journal of Social Work Practice, 34(4), 411-424. https://doi.org/10.1080/02650533.2020.1844166

Hill, M. O. (2004). Dreaming the End of the World: Apocalypse as a Rite of Passage. Spring Publications.

Hoggett, P. (Ed.) (2019). Climate Psychology: On indifference to disaster. Palgrave Macmillan.

Huyssen, A. (2006). Nostalgia for Ruins. Grey Room, 23(Spring), 6-21.

Jensen, T. (2019). Ecologies of Guilt in Environmental Rhetorics. Palgrave Macmillan.

Johnson, K. (2020, March 9). An Economic Pandemic. Foreign Policy. https://cutt.ly/amnelOi

Jämsén, E. (2020, April 11). Koronaviruspandemia merkki lopun ajoista? Osalle uskonnollisista liikkeistä Ilmestyskirjan ennustukset ovat käymässä toteen, osa ei näe koronaa viimeisenä merkkinä. [Corona pandemic a sign of end of times? Some religious movements see the prophecies of the Book of Revelations coming true, others do not see COVID-19 as final sign.] YLE. https://cutt.ly/amneOIN

Kecmanovic, J. (2020, March 10). 7 Science-based Strategies to Cope with Coronavirus Anxiety. The Conversation. https://cutt.ly/1mneP4L

Kermode, F. (1968). Sense of an Ending: Studies in the Theory of Fiction. Oxford University Press.

Kiviniemi, E. (2020, April 2). Pentti Linkola ei näe toivoa: 'Ei yksi virus juuri mitään muuta.' [Pentti Linkola sees no hope: 'One virus won't change much'] Kulttuuritoimitus. https://cutt.ly/ QmneDeO

Krohn, E. (2020, April 9). Onko intellektuellien aika ohi? [“Is the time of intellectuals over?”] Kulttuurivihkot. https://cutt.ly/ymneGtO

Lahtinen, T. (2018). The Tale of the Great Deluge: Risto Isomäki's The Sands of Sarasvati as Climate Fiction. In, R. Hennig, A-K. Johansson \& P. Degerman, Nordic Narratives of Nature and the Environment (pp. 7996). Lexington Books.

Lakh, E., Shamri-Zeevi, L., \& Kalmanowitz, D. (2021). Art in the time of corona: A thematic analysis. The Arts 
in Psychotherapy, 75, 101824. https://doi.org/10.1016/j.aip.2021.101824

Lakhani, N. (2020, April 2). ‘A perfect storm': US facing hunger crisis as demand for food banks soars. The Guardian. https://cutt.ly/6mneHmo

Lang, O. (2020, April 21). Coronavirus dreams: Why are people having lockdown nightmares? https://www. bbc.com/news/av/health-52354371

Larsen, S. E. (2004). The City as a Postmodern Metaphor. KONTUR, 10, 27-33.

Leahy, R. L. (2020, April 17). Coronavirus Anxiety. Psychology Today. https://cutt.ly/kmneJjX

Leetaru, K. (2020, March 2). Media Coverage and Coronavirus Panic: What the Numbers Show. Real Clear Politics. https://cutt.ly/gmneKwC

Lepistö, J. (2020, March 26). Syntyvyys lähti nousuun vuosien jälkeen - asiantuntijat eri mieltä, miten korona tulee vaikuttamaan lukuihin. [Birth rate on the rise after years - experts disagree on how COVID-19 will impact figures.] MTV. https://cutt.ly/6mneLIT

Levenson, E. (2020, April 2). Officials keep calling the coronavirus pandemic a 'war.' Here's why. CNN. https://cutt.ly/6mneXON

Lifton, R. J. (2019). Losing Reality: On cults, cultism, and the mindset of political and religious zealotry. The New Press.

Lockwood, A. (2012). The Affective Legacy of Silent Spring. Environmental Humanities, 1(1), 123-140. https:// cutt.ly/YmneVRe

Lowe, T., Brown, K., Dessai, S., de Franca Doria, M., Haynes, K., \& Vincent, K. (2006). Does tomorrow ever come? Disaster narrative and public perceptions of climate change. Public Understanding of Science, $15,435-457$.

Löyttyniemi, R. (2020, March 26). Korona on historiallisesti poikkeuksellinen kriisi - vai onko sittenkään? [Corona is a historically exceptional crisis - or is it?] YLE. https://cutt.ly/kmneBHu

Mazza, E. (2020, June 4). Devin Nunes Claims Homeless Are Like A 'Zombie Apocalypse' Amid Coronavirus. Huffpost. https://cutt.ly/xmneNRP

Morton, T. (2007). Ecology Without Nature: Rethinking Environmental Aesthetics. Harvard University Press.

Neate, R. (2020, March 10). Super-rich jet off to disaster bunkers amid coronavirus outbreak. The Guardian. https://cutt.ly/umneMno

Niinistö, M. (2020, April 26). Oletko nähnyt levottomia unia viime aikoina? Niin on moni muukin ympäri maailmaa - pandemiaunien syitä ryhdytään selvittämään. [Have you had restless dreams lately? So have many others around the world - new investigations into the reasons for pandemic dreams.] YLE. https://cutt.ly/omne1Em

Onali, A. \& Mahlamäki, H. (2020, March 15). Koulut suljettiin Virossa ja Berliinissä, ja se vie perheitä neljän seinän sisälle pitkäksikin aikaa. Helsingin Sanomat, p. A11. https://www.hs.fi/ulkomaat/art2000006440436.html

O'Sullivan, S. (2020, January 24). Coronavirus 'zombies' roaming Britain for weeks before deadly symptoms emerge, warn experts. The Sun. https://cutt.ly/ZmnezlK

Pelli, P. (2020, April 21). Eniten koronakriisissä on yllättänyt Ruotsin kyky katsoa pois päin kuolleistaan. [The most surprising thing in the corona crisis is Sweden's ability to look away from its deceased.] Helsingin Sanomat. https://www.hs.fi/ulkomaat/art-2000006481667.html

Pihkala, P. (2020a). 'Corona anxiety' and Climate Anxiety. A lecture video, March 25, 2020. https://cutt.ly/ dmne3jz

Pihkala, P. (2020b). Anxiety and the Ecological Crisis: An Analysis of Eco-anxiety and Climate Anxiety. Sustainability, 12(19), 7836. https://doi.org/10.3390/su12197836

Pihkala, P. (2020c, April 3). Climate grief: How we mourn a changing planet. BBC Climate Emotions series. https://cutt.ly/5mne829

Pihkala, P. (2019). Keskusteluryhmiä ympäristöahdistuksesta. [Discussion groups about eco-anxiety]. Report. Helsinki: Mieli ry Mental Health Finland. https://cutt.ly/Nmne43s 
Potash, J.S., Kalmanowitz, D., Fung, I., Anand, S.A. \& Miller, G.M. (2020). Art Therapy in Pandemics: Lessons for COVID-19. Art Therapy, 37(2), 105-107. https://doi.org/10.1080/07421656.2020.1754047

Purdy, L. (2017, February 8). Today's ecological crisis is a rite of passage for humanity. Positive News Magazine. https://cutt.ly/imne7VS

Ratcliffe, R. (2020, March 13). Mass monkey brawl highlights coronavirus effect on Thailand tourism. The Guardian. https://cutt.ly/Amne5D9

Silverman, G. (2020, March 23). The Coronavirus Is A Media Extinction Event. BuzzFeed News. https://cutt. ly/Vmnrqqx

Sittler, J. (1976). Space and Time in American Religious Experience. Union Seminary Review, 30(1), 44-51. https://doi.org/10.1177/002096437603000106

Skrimshire, S. (Ed.) (2010). Future Ethics: Climate Change and Apocalyptic Imagination. Bloomsbury Publishing.

Slovic, P. \& Västfjällen, D. (2015). The More Who Die, the Less We Care: Psychic Numbing and Genocide. In, S. Slovic \& P. Slovic (editors). Numbers and Nerves: Information, Emotion, and Meaning in a World of Data (pp. 27-41). Oregon State University Press.

Steffen, W., Richardson, K., Rockström, J., Cornell, S. E., Fetzer, I., Bennett, E., ... Vries, d., W. (2015). Planetary boundaries: Guiding human development on a changing planet. Science, 347(6223), 1259855. https:// doi.org/10.1126/science.1259855

Stoll, M. (2009). Rachel Carson: The Presbyterian Genesis of Silent Spring. In, N. A. Rupke (editor). Eminent Lives in Twentieth-Century Science \& Religion (pp. 47-72). Peter Lang.

Taylor, S., Landry, C. A., Paluszek, M. M., Fergus, T. A., McKay, D., \& Asmundson, G. J. G. (2020). COVID stress syndrome: Concept, structure, and correlates. Depression and Anxiety, 37(8), 706-714. https://www. doi.org/10.1002/da.23071

Turner, V. (1969). The Ritual Process: Structure and Anti-structure. Routledge.

Wallin, A. \& Peltomaa, J. (2020, March 21). Koronavirus vaatii arvioimaan uudelleen kaupungistumisen edistämisen - Ruuhkaisissa kaupungeissa taudit leviävät nopeasti. [Corona virus demands a reevaluation of urbanization - diseases spread quickly in dense cities.] Aamulehti. https://www. aamulehti.fi/a/12cc563d-ddoo-424d-81c8-47e408a5b6cf

The Weather Channel (2020, April 24). Himalayas Visible for First Time in 30 Years Due to Lockdown. https://cutt.ly/MmnrtOk

Weaving, S. (2020, March 30). Scary red or icky green? We can't say what colour coronavirus is and dressing it up might feed fears. The Conversation. https://cutt.ly/KmnryYf

Wray, M. (2020, March 18). Dolphins return to Italy's coast amid coronavirus lockdown: 'Nature just hit the reset button'. Global News. https://cutt.ly/Smnrigy

Zalan, E. (2020, April 2). Journalism hit hard by corona crisis. EuObserver. https://euobserver.com/ coronavirus/147956

\section{AUTHORS}

Toni Lahtinen. Acting Senior Lecturer of Finnish Literature at the University of Helsinki, Finland.

Panu Pihkala. Adjunct Professor (Title of Docent) in Environmental Theology, University of Helsinki

\section{Conflict of interest}

No potential conflict of interest is reported by the authors.

\section{Funding}

Toni Lahtinen: Academy of Finland research project "Environmental Risks, Dystopias and Myths in Contemporary Literature (310919)", 2017-2020; Panu Pihkala: The Finnish Cultural Foundation, personal grant (granted February 2019)

Acknowledgments

$$
\mathrm{N} / \mathrm{A}
$$

